\title{
MEMBANGUN KEPERCAYAAN MASYARAKAT PADA MADRASAH MELALUI PAMEREN PENDIDIKAN
}

\author{
Nurul Yaqien
}

Dosen pada program studi PGMI UIN Malang

\begin{abstract}
Madrasah exhibition is an attempt of Islamic educational institution to acquaint itself to public till people know of its existence, advantages and superiority than the other schools. The exhibition is expected to demonstrate excellences of madrasah that will change public views so far, which are assumed madrasah is identical as backward, dirty and not advanced. Madrasah excellences are displayed on the society will make people excited and interested in Islamic educational institutions. The image and degrees of madrasah will be lifted as one of the advanced Islamic education institutions.

Key word: Trust, Public, Exhibition, Madrasah
\end{abstract}

\section{A. Pendahuluan}

“Tak kenal maka tak sayang, tak sayang maka tak cinta," ini ungkapan yang sering di dengar oleh masyarakat umum dalam proses mencintai seseorang. Ungkapan itu dapat di realisasikan atau manifestasikan dalam dunia pendidikan. Membangun kepercayaan masyarakat terhadap lembaga pendidikan tidak akan muncul sebelum lembaga tersebut mengenalkan jati dirinya. Setelah mengenal lebih dalam, maka akan timbul perasaaan suka atau sebaliknya. Jika lembaga pendidikan tersebut memperkenalkan sesuatu kelebihan-kelebihan, prestasi, keunggulan-keunggulan, serta kurikulum yang meyakinkan, maka rasa percaya itu akan muncul pada diri seseorang dan akan menimbulkan sebuah pencitraan yang sangat berharga bagi lembaga pendidikan yang bersangkutan

Kepercayaan merupakan modal awal bagi lembaga pendidikan yang harus ditumbuh-kembangkan dalam jiwa masyarakat. Kepercayaan akan timbul dalam diri masyarakat apabila mereka membuktikan bahwa madrasah tersebut memiliki prestasi-prestasi akademik yang gemilang, unggul dalam membentuk jiwa manusia yang beriman dan bertaqwa, 
cerdas dalam berfikir, dan memiliki jiwa sosial yang tinggi. Prestasi dan keunggulan akan dijadikan produk utama bagi setiap lembaga pendidikan yang ingin menjadikan dirinya terdepan. Dalam pameran pendidikan yang sering dikedepankan adalah hal-hal yang berkaitan dengan pencapaian prestasi siswa dalam bidang akademik maupun non akademik dengan harapan masyarakat yang menyaksikan pameran tersebut tertarik dan memberikan kepercayaan penuh pada sekolah untuk berbondongbondong mempercayakan pendidikan putra-putrinya pada lembaga pendidikan yang unggul tersebut.

\section{B. Sekilas Sejarah Madrasah}

Latar belakang perlunya madrasah melaksanakan atau mengikuti pameran adalah agar masyarakat yang selama ini memiliki anggapan bahwa madrasah adalah tempat yang kurang layak, terkesan sebagai pendidikan yang "asal-asalan" tidak serius dalam mendidik anak itu menjadi hilang. Oleh karena itu, madrasah harus menampilkan dirinya bahwa madrasah dapat mencetak manusia yang berkualitas. Manusia berkualitas tercermin pada diri anak didik yaitu memiliki kesalehan pribadi (memiliki imtaq dan cerdas) dan kesalehan sosial.

Pada paparan sejarah pendidikan Islam (madrasah) akan terlihat bahwa pendidikan Islam pada saat itu terkesan sebagai pendidikan yang tradisional dan jauh dari sentuhan-sentuhan kemajuan. Oleh karena itu, kondisi tersebut secara alamiah akan membangun image masyarakat bahwa pendidikan Islam identik dengan pendidikan yang terbelakang yang hanya dikonsumsi oleh rakyat kecil. Anggapan terhadap kondisi pendidikan Islam ini, akan menimbulkan asumsi bahwa penyelenggaraan pendidikan Islam ketika itu diselenggarakan dengan apa adanya. Selain itu asumsi-asumsi terhadap pendidikan ini juga di kuatkan oleh adanya kondisi pendidikan Islam yang kurang mendapat perhatian penuh dari pemerintah (waktu itu), sehingga pendidikan Islam termarginalkan dari pada pendidikan umum.

Sejarah juga mencatat bahwa awal penyelenggaraan pendidikan Islam dilakukan oleh para wali yang terkenal sebagai peletak dasar pendidikan Islam di Indonesia. Para wali khusunya di tanah jawa dipandang telah merintis berdirinya lembaga pendidikan Islam yang kemudian dikenal dengan nama Pesantren (Djumhur dan Danasaputra, 1990:112). Walaupun pada perkembangannya banyak rintangan yang 
harus dihadapi. Menurut Bawani (1987:49) diantara rintangan itu adalah dengan datangnya para penjajah Belanda yang ingin mengambil alih posisi pendidikan Islam untuk dijadikan tempat mencetak tenaga-tenaga kerja murahan guna kepentingan kolonial Belanda sendiri, walaupun pada akhirnya pemerintah Belanda gagal untuk mengalihkan posisi pendidikan Islam tersebut. Kegagalan ini menjadikan mereka berfikir untuk memilikinya. Akhirnya mereka memiliki inisiatif untuk mendirikan sekolah sendiri sebagai alternatif pendidikan yang sesuai dengan keinginannya. Pendidikan kolonial Belanda ini-lah yang pada akhirnya menjadi bibit dari munculnya sekolah umum.

Secara historis, Ia juga menyebutkan bahwa apa yang dilakukan oleh Belanda tersebut merupakan awal terjadinya berbagai macam pendidikan di Indonesia. "Setelah Indonesia merdeka, pendidikan umum mengalami peningkatan yang cukup pesat jika dibandingkan dengan pendidikan Islam." Peningkatan perkembangan pendidikan umum ini terjadi karena pendidikan umum pada waktu itu telah diambil alih oleh pemerintah Indonesia dan diarahkan pada pendidikan yang berorientasi pada pengembangan kualitas masyarakat dibidang umum. Seperti mencetak tenaga pegawai atau tenaga-tenaga yang berorientasi pada dunia kerja. Sedangkan pesantren dan pendidikan madrasah yang ada di dalamnya tidak banyak mengalami perubahan bahkan dapat dikatakan statis (Bawani, 1987: 49).

Dari sinilah, persoalan-persoalan pendidikan Islam itu muncul. Persoalan dari perspektif kurikulum yang perlu dikaji ulang, serta anggaran dana yang relatif minim (Faisal,1995:120), maupun kualitas lulusannya yang masih jauh dari harapan (standar kualitas ilmu pengetahuan umumnya). Oleh karena itu, pemerintah berusaha untuk menyeragamkannya dengan mengeluarkan surat keputusan surat bersama tiga mentri pada tahun 1975 yang isinya menyangkut mutu madrasah yang diharapkan dapat sejajar dengan sekolah umum. Berangkat dari kondisi ini pula tampak bahwa kualitas madrasah (pendidikan Islam) sangat jauh jika dibandingkan dengan pendidikan umum (pada waktu itu).

Kemudian muncul persoalan yang baru yaitu, pada waktu pelaksanaan SKB tiga mentri tersebut, terjadi adanya kecaman yang di alamatkan pada madrasah yang melaksanakan keputusan itu. Ternyata mutu pengetahuan agama lebih-lebih bahasa arab menjadi amat rendah. Rendahnya kualitas pendidikan tersebut disebabkan oleh kondisi siswa 
yang mengharuskan mereka untuk menguasai dua mata pelajaran. Selain mereka memikirkan mata pelajaran agama yang sangat banyak, mereka juga harus memikirkan pelajaran-pelajaran umum yang juga cukup banyak, serta membutuhkan waktu yang banyak pula. Sehingga yang terjadi adalah beban pelajaran yang terkesan amat berat. Karena memang kurikulum pada saat itu belum diformat dengan baik. Oleh karena itu, berbagai hal inilah yang menyebabkan rendahnya kualitas peserta didik.

Keadaan inilah yang menyebabkan masyarakat mempunyai image bahwa lembaga pendidikan yang berlabelkan agama cendrung mengarah pada pendidikan yang terbelakang dan jauh dari kualitas pendidikan yang diharapkan. Image tersebut didasarkan pada beberapa faktor yang menyebabkan pendidikan Islam terkesan pendidikan yang terbelakang. "Diantaranya yaitu tidak terpenuhinya beberapa maksud pemerintah dalam melaksanakan pembangunan dalam sektor agama, khususnya agama Islam. Faktor-faktor tersebut antara lain adanya anggapan di masyarakat bahwa lulusan sekolah agama lebih-lebih para sarjananya dipandang nilai gengsinya lebih rendah dibandingkan dengan para insinyur, dokter dan sarjana-sarjana lain non agama. Anggapan ini secara langsung maupun tidak telah membawa dampak psikologis dan kesenjangan sosial pendidikan, sehingga muncul anggapan bahwa sarjanasarjana non agama dipandang memiliki masa depan jauh lebih baik dari pada sarjana-sarjana agama" (Mustofa dan Ali,1997:151).

Oleh karena itu, masyarakat enggan untuk menitipkan putraputrinya kelembaga pendidikan yang berlabelkan agama Islam. Apalagi bagi mereka masyarakat yang termasuk dalam golongan "the have", Tentu mereka tidak ingin putra-putrinya menjadi gagal dalam pendidikan yang diakibatkan dari kesalahan penempatan pendidikan anak-anak mereka yang cendrung pada kurangnya fasilitas maupun rendahnya kualitas pendidikannya.

Keadaan demikianlah yang menyebabkan munculnya alasan bagi mereka yang memiliki keuangan lebih untuk berbondong-bondong mempercayakan pendidikan putra-putrinya keluar negeri diantara alasannya adalah memiliki keuntungan lebih, klaim Hariyanto, Pertama, mereka bisa langsung merasakan pergaulan interasional karena mereka langsung datang dan tinggal di lingkungan tersebut. Keuntungan lainnya adalah pelajaran bahasa Inggris yang menjadi lebih baik dan bisa menjadi modal bagi pergaulan internasional. Orang tua punya harapan besar ketika 
menanamkan investasi pendidikan bagi anak mereka bersekolah di luar negeri. Oleh karena itu, mereka harus membawa keuntungan ketika kembali ke negeri ini. Selain mereka dihargai tinggi saat bekerja, mereka juga bisa mengamalkan ilmu itu di dalam negeri, kata salah satu pembicara Charles Bonar Sirait (Media Indonesia; 2008:1)

Pendidikan agama semacam ini banyak diselenggarakan oleh orang-orang NU (Nahdhotul Ulama') yang memiliki jumlah jama'ah terbesar di Indonesia. Jama'ah NU yang besar inilah yang kemudian mengharuskan tokoh-tokoh NU untuk menyelenggarakan pendidikan sebagai sarana pendidikan bagi para warganya. Keadaan semacam ini ternyata bukan hanya terjadi pada orang-orang NU saja, akan tetapi juga terjadi pada orang-orang Muhammadiyyah. "Entah berapa ribu madrasah dan sekolah disamping pesantren yang bernaung dibawah NU dan Muhammadiyyah, yang diselenggarakan dengan 'asal buka'. Dimana kondisi tersebut tidak banyak didukung oleh komponen-komponen obyektif yang dibutuhkan dalam penyelenggaraan pendidikan. Sehingga ada beberapa titik lemah yang harus diperbaiki dalam pembinaannya, diantaranya yaitu, sumber dana, manajemen, sarana dan tenaga"(Hasan,1993:52-53).

Sejarah keberadaan madrasah inilah yang menjadikan image madrasah jatuh, maka perlu madrasah untuk segera merubah pandangan masyarakat bahwa madrasah pada awal abad XX ini, juga merupakan pendidikan yang maju dan berkualitas bahkan memiliki kualitas yang plus jika di bandingkan dengan sekolah umum. Dengan adanya pameran tentang pendidikan madrasah maka keberadaan madrasah akan di perhitungkan dalam persaingan dalam dunia pendidikan.

\section{Alasan Perlunya Pameran Pendidikan}

Setiap orang membutuhkan informasi. Apalagi informasi tersebut sangat dibutuhkan oleh seseorang yang ingin mencetak buah hatinya menjadi manusia yang berkualitas. Bahkan orang rela membayar berapapun hanya demi mengetahui informasi yang ia butuhkan. Terkait dengan informasi pendidikan ini, banyak orang tua yang masih bingung mau di sekolahkan dimana putra-putrinya agar harapan dia sebagai orang tua tercapai.

Seperti yang terjadi di daerah purworejo, banyak anak maupun orang tua yang membutuhkan informasi tentang pendidikan yang berkualitas. Seperti statment berikut ini: “Semua orang tak terkecuali warga 
Purworejo sangat memperhatikan pentingnya sebuah pendidikan seiring dengan meningkatnya taraf hidup masyarakat. Pendidikan adalah sebuah kunci utama untuk memajukan bangsa dan memperbaiki kesejahteraan manusia, tidak heran jika saat ini banyak orang tua siswa yang sangat memperhatikan jalur pendidikan bagi anak-anaknya. Setiap jalur pendidikan yang ditempuh oleh seorang pelajar baik SD, SMP, SMA maupun Tingkat PT akan sangat menentukan masa depan pelajar tersebut. Namun bagaimana jika info tentang pendidikan tidak tersedia secara aktual dan faktual sehingga menimbulkan keraguan pelajar dalam penentuan keputusan untuk melanjutkan jenjang pendidikannya menuju tingkat yang lebih tinggi.

Contoh: tidak semua SMA di purworejo mendapatkan promosi, padahal peminat PT bisa berasal dari SMA mana saja di Purworejo. Dan alasan yang biasanya diutarakan oleh Mahasiswa asal Purworejo dari suatu PT yang mengadakan promosi terkait dengan tidak diadakannya promosinya ke beberapa SMA yang lainnya ialah masalah tenaga dan waktu yang terbatas, sehingga promosi hanya diadakan pada SMA tertentu saja. Mungkin inilah yang menjadi jawaban kenapa hanya beberapa SMA yang itu-itu saja di Purworejo yang banyak memberikan supply Mahasiswa ke PT. Lalu solusi apa yang dapat ditawarkan?, maka Purta mencoba untuk berbicara dan menjawab, "Pameran Pendidikan" (purta,2008;1-2)

Pentingnya diadakan pameran pendidikan di atas merupakan bukti bahwa sebagian masyarakat membutuhkan informasi tentang keberadaan pendidikan yang sangat di butuhkan baik untuk mengawali pendidikan bagi putra putrinya, maupun untuk melanjutkan kejenjang pendidikan yang lebih tinggi. Maka madrasah yang merupakan model pendidikan Islam yang maju perlu mengadakan atau mengikuti pameran untuk merubah image sebelumya, yaitu merubah kesan bahwa madrasah merupakan pendidikan yang terbelakang menjadi pendidikan yang unggul, maju dan berkualitas.

\section{Pengertian Pameran}

Pameran merupakan penyebaran pesan informatif, persuasif dan sebagai sarana komunikasi yang membuat masyarakat tetap menjadi ingat dan mengerti tentang apa yang di tampilkan pada pameran tersebut. Penyebaran pesan melalui pameran, akan membentuk pengetahuan masyarakat tentang apa saja yang telah di tampilkan oleh madrasah. 
Kemudian pengetahuan tersebut dapat diserap melalui indara manusia yang dapat mempengaruhi ingatan pengunjung pameran, seperti yang diungkapkan oleh Ruslan bahwa pengetahuan yang diserap oleh indra manusia meliputi: Mata (sight) 70\% pendengaran (hearing) $13 \%$ sentuhan (touch) 6\% penciuman (smell) 3\% dan Cita Rasa (taste) 3\% dan unsur-unsur indra manusia ini digunakan dalam pameran (Ruslan: 2002: 245).

Dalam hubungan masyarakat pameran merupakan kegiatan yang menunjukkan sesuatu kepada orang banyak mengenai kelebihan dan keunggulan yang dimiliki oleh sesuatu tersebut (Ruslan: 2002:246). Dalam bidang pendidikan pameran madrasah merupakan upaya penampilan kelebihan dan keunggulan yang dimiliki oleh madrasah untuk diketahui, dipahami, sehingga timbul simpati bahkan empati bagi yang menyaksikan pameran tersebut.

\section{E. Tujuan Pameran}

Tujuan pameran madrasah adalah bukan menjual produk supaya barang dagangannya terjual akan tetapi, memberikan program-program dan kegiatan yang telah dicapai oleh madrasah, kepada pengunjung (masyarakat) yang diharapkan pengunjung tertarik dengan program program yang proses pendidikan yang dilakukan pada madrasah tersebut.

Adapun pelaksanaan pameran dalam dunia pendidikan pada umumnya memiliki beberapa tujuan yang sangat dibutuhkan dalam rangka mengenalkan, membangun Image, dan citra sebuah lembaga pendidikan yang pada akhirnya akan menimbulkan kepercayaan terhadap lembaga pendidikan tersebut baik sekolah atau madrasah. Tujuan diadakannya pameran diantaranya:

1. Mengenalkan nama lembaga pendidikan tertentu agar lebih akrab di telinga masyarakat

2. Mengealkan visi misi pendidikan yang berkaitan dengan kemajuan zaman

3. Mengenalkan prestasi-prestasi yang pernah di raih dalam eveneven nasional maupun internasional.

4. Menarik para pengunjung pameran untuk mempercayaakan pendidikan putra-putrinya ke lembaga pendidikan tertentu dengan menampilkan berbagai produk dan atraksi hasil karya siswanya. 
5. Mengenalkan beberapa keunggulan yang dimiliki oleh lembaga pendidikan kepada pengunjung pameran di banding dengan pendidikan yang lain.

6. Menciptakan pencitraan terhadap lembaga yang dipromosikan atau dipamerkan.

\section{F. Mekanisme Pameran}

Sebelum madrasah mengikuti kegiatan pameran atau mengadakan pameran ada beberapa yang perlu di persiapkan berkaitan dengan pelaksanaan acara tersebut diantaranya adalah:

1. Madrasah memberikan pesan-pesan kepada setiap calon peserta pameran (pengunjung). Dalam hal ini media humas yang digunakan adalah Pos (stand) atau pusat penerangan yang melayani segenap peserta dan pengunjung pameran terutama dari kalangan media masa (Anggoro: 2001:168). Baik media elektronik maupun media cetak. Pada saat pembukaan pameran panitia pameran hendaknya mengundang pers yang diharapkan pers tersebut mengkomunikasikan kepada masyarakat bisa melalui tulisan (koran,majalah, tabloit dll) maupun siaran radio dan televisi yang dapat di dengar dan dilihat oleh masyarakat luas.

2. Pada saat pameran berlangsung diperlukan adanya pemandu yang membantu menjelaskan secara verbal data-data yang ada dalam pameran. Untuk meningkatkan kualitas komunikasi maka diperlukan adanya data-data yang di dukung oleh penjelasan melalui komunikasi non verbal misalkan melalui pamflet, brosur yang di disain dengan menarik dan memikat. Publikasi melalui pamflet, brosur ini akan menyebarkan pesan-pesan dari pihak penyelenggara kepada ribuan orang baik di dalam maupun di luar negeri.

3. Selain pos (stand) digunakan untuk menjelaskan kepada masyarakat tentang kelebihan dan prestasi peserta didiknya pos juga dapat digunakan sebagai tempat menampilkan berbagai demonstrasi baik pertunjukan film prestasi peserta didik maupun demontrasi prestasi secara langsung kepada pengunjung pameran (Anggoro; 2001:187)

\section{G. Perencanaan Pameran}


Jika pameran direncanakan dengan matang, maka pihak madrasah akan memiliki banyak kesempatan berhubungan dengan masyarakat dalam mempromosikan lembaga pendidikannya. Para peserta pameran harus sudah menetapkan rencana kegiatan pameran sebelum mengambil keputusan untuk ikut melaksanakan pameran, yaitu dengan memesan tempat atau stand. Pemesanan tempat biasanya dilakukan jauh-jauh hari sebelum acara pameran diselenggarakan. Oleh karena itu peserata pameran harus mempertimbangkan secara matang tentang apakah layak pameran untuk di ikuti ataukah tidak dengan mempertimbangkan beberapa hal diantaranya:

1. Apakah pameran itu diselenggarakan oleh perusahaan yang terkenal ataukah tidak? hal ini untuk mengantisipasi kurangnya pengunjung jika tidak dilakukan dengan profesionaln termasuk juga apakah ia sebelumnya sudah melaksanakan pameran barang ataukah yang serupa dengan pameran-pameran sosial ataukah tidak?

2. Apakah waktu pameran tidak berbenturan dengan kegiatan madrasah yang tidak kalah pentingnya.?

3. Apakah tempat pameran tersebut cukup bagus dan bisa menarik pengunjung yang relevan dalam jumlah yang besar?

4. Apakah lokasi pameran mudah dijangkau mengangkut dan membawa pulang barang-barang atau benda-benda pameran.? Sebab tempat pameran yang terlalu jauh biasanya menimbulkan masalah dalam pengangkutan dan sarana transportasi untuk mengunjungi pameran tersebut

5. Apakah tempat pameran tersebut memiliki lahan parkir yang memudahkan bagi pengunjung untuk memarkir kendaraannya dengan baik mudah dan aman.

6. Biaya stand apakah bisa di jangkau taukah tidak dengan dipertimbangkan dengan hasil yang akan di capai dalam pelaksanaan pameran.

7. Keberadaan sarana peserta pameran seperti: air, jangkauan telp, listrik, keamanan apakah tersedia jika sewaktu-waktu dibutuhkan. 
8. Publikasi panitia pameran, bagaimana publikasi yang dilakukan oleh panitia pameran apakah akan bisa menarik pengunjung ataukah tidak.

9. Bongkar pasang stand apakah tersedia waktu yang cukup untuk memasang dan membongkar stand sebelum dan sesudah pameran berlangsung?

10. Apakah kunjungan petugas pers dan para wartawan di atur oleh pihak penyelenggara pameran? sebab pers merupakan aspek pameran yang harus diperhatikan oleh setiap peserta pameran, karena melalui pameran itu mereka berminat memperoleh liputan yang mendukung oprasional.

11. Kegiatan-kegiatan yang terkait, apakah ada kegiatan lain yang bersifat mendukung, dan berkaitan dengan pameran tersebut.

12. Apakah biaya sepadan antara ongkos merancang dan mendirikan stand, sewa tempat, biaya mencetak penjualan, biaya menyambut pengunjung, dan biaya langsung yang menggunakan tenaga sebagaian staf sehingga mereka terpaksa meninggalkan pekerjaan sehari-hari untuk mengurus pameran tersebut. (Fakhrudi: 1994: 191 192)

Perencanaan ini semakin mantap apabila ditampilkan karakteristik khusus dalam pameran pada sebuah lembaga pendidikan (madrasah) yang dapat menarik perhatian halayak sebagai obyek maupun subyek adapun karakteristik itu dapat diuraikan sebagai berikut:

1. Mudah menarik perhatian kelebihan pameran terletak pada kemampuannya dalam membangkitkan dan mengarahkan perhatian halayak terhadap subyek yang dipamerkan. Ini bisa dilakukan dengan mengundang kalangan pers.

2. Waktu yang luang, bila ingin tampil beda dengan dapat menarik perhatian orang banyak dalam penyelenggaraan pameran sekolah segenap persiapan para personil pelaksanaannya memerlukan waktu yang lama agar para penjaga stand mempunyai kompetensi menjelaskan terhadap pertanyaan dari para pengunjung.

3. Peluang percobaan prototib. Disini banyak peluang untuk memajang berbagai produk baru. Dalam madrasah dapat menampilkan karya-karya baru hasil dari daya kreatifitas siswa. 
4. Peluang pertemuan tatap muka. Kepercayaan kredibilitas dan nama baik suatu perusahaan dalam konteks ini sekolah bisa diperkuat dan diperkokoh melalui tatap muka secara langsung dengan para pengunjung pameran.

5. Acara demonstrasi dan pembagian sampel ini merupakan upaya penampilan nyata kepada masyarakat. Dalam sekolah menampilkan kebolehan-kebolehan dari produk-produk sekolah yang bersangkutan pada sebuah panggung untuk mengekspos diri pada halayak.

6. Adanya suasana akrab dalam pameran. Pameran dibuat sebagai wahana rekreasi, sehinga pengunjung merasa betah meskipun mereka berjalan kakidalam menyaksikan pameran tersebut bagi masyarakat. Bahwa membangkitkan empati merupakan suatu yang urgen dalam pameran sekolah (Kusumasturi: 2002: 191).

\section{H. Unsur-Unsur Personalia Yang Dilibatkan Dalam Pameran}

Dalam pelaksanaan pameran ini yang sangat memiliki peran adalah wakil kepala madrasah bidang kehumasan. Menurut Anggoro organisasi humas mungkin hanya terdiri dari manajer dan seorang sekertaris, namun banyak pula yang mempekerjakan para asisten spesialis seperti pejabat editor, pers, jurnal internal, perancang media cetak, foto grafer. Oleh karena itu dapat ditarik kesimpulan bahwa struktur organisasi secara umum meliputi manajer, wakil manajer, sekertaris, asisten manajer meliputi: editor internal, pengatur kunjungan, fotografer, percetakan dan publikasi dan petugas pers (Anggoro: 2001: 108)

Adapun dalam pelaksanaan pameran lembaga pendidikan maka pihak-pihak yang dilibatkan meliputi:

1. Kepala madrasah

2. Wakil kepala madrasah bagian humas

3. Wakil kepala madrasah bagian kesiswaan

4. Pembina Osis

5. Guru dan Siswa

\section{Bentuk-Bentuk Pameran}

Di daerah Eropa dan Amirika Serikat Utara, di sana cuaca begitu sulit. Sebagian besar acara pameran di selenggarakan di dalam ruangan, 
sebaliknya di negeri-negeri tropis yang memiliki suhu udara yang hangat dan cuaca yang stabil, acara-acara pameran lebih sering diadakan di luar ruangan. Pada dasarnya bentuk-bentuk pameran dapat diklasifikasikan sebagai berikut:

1. Pameran umum (Public Exhibition) yakni pameran yang bertujuan untuk memperkenalkan suatu organisasi atau produknya, atau suatu hal khusus kepada halayak umum. Salah stu contohnya adalah pameran rumah atau pameran mebel yang sering di adakan di balai sidang senayan.

2. Pameran dagang (Trade Exhibition) yakni suatu pameran yang khusus bagi kalangan atau pihak tertentu, mulai dari pengunjung pameran, perusahaan-perusahaan bonafit, calon pembeli, instansi pemerintah yang menangani perdagangan dan unsur-unsur lainnya dan komunitas bisnis. Misalnya pameran produk komputer, pameran mobil terbaru, pameran mabel dan seterusnya. Selain untuk menarik perhatian halayak, pameran dangang ingin bertujuan untuk mencetak transaksi jual beli secara langsung pada lokasi pameran.

3. Pameran diluar ruangan (Outdoor Exhibition) yakni pameran yang menampilkan produk berukuran besar, misalnya pameran produk-produk pertanian dan pameran pedesaan lainnya.

4. Pameran terbatas (Private Exhibition) Diadakan dalam ruang baik itu dalam sebuah gedung milik sendiri mupun di gedung sewaan

5. Pameran dagang luar negeri (Overseas Trade Fairs) yang khusus di selenggarakan dalam rangka mempromosikan produk-produk buatan suatu negara di negara lain, dan menarik minat para pembeli atau importir setempat. Pameran ini sering pula diikuti oleh banyak negara sehingga menyerupai suatu pameran international dimana masing-masing negara mempunyai pavilion atau gerai tersendiri untuk memamerkan berbagai macam produknya.

6. Pameran patungan (Joint Venture Exhibition) yakni pembukaan suatu gerai yang melibatkan beberapa peserta.

7. Pameran keliling (Mobile Show) yakni suatu pameran yang biasa di selenggarakan secara berpindah-pindah dari tempat yang satu 
ketempat yang lain. Berbagai macam barang yang dipamerkan diangkut dengan kereta api barang, trailer, pesawat atau truk, banyak pula exportir yang sengaja mengadakan pameran di pelabuhan-pelabuhan, dinama produk yang di pamerkan di bawa oleh kapal.

8. Pameran jinjing (Portable Exhibition) yakni suatu pameran yang perangkatnya begitu ringkas sehingga mudah di bawa kemanamana. Gerai yang dipakai juga ringkas sehingga gampang dilipat serta diangkat penyelenggara. Pameran ini bisa diadakan oleh perusahaan swasta, bisa pula instansi pemerintah.

9. Pameran kecil (Small Exhibition) yang biasa diadakan pada sebuah pojok atau sudut toko, beranda hotel, dan di emperan station atau bandar udara, barang yang di pamerkan dapat dikemas dalam kotak-kotak atau di letakkan di etalase ditumpukkan pada panel pameran atau bisa juga di tempatkan pada suatu acara khusus secara permanen. Disamping panel pameran perangkat penting lainnya yang selalu digunakan adalah sample foto dan baganbagan.

10. Acara pekan belanja atau pekan promosi (Shopping Weeks) yang seringkali di sponsori oleh pemerintah, asosiasi perdagangan, perusahaan manufaktur, dan badan promosi pariwisata tau lembaga-lembaga lainnya. Acara tersebut sering diselenggarakan oleh tiko-toko terkemuka biasanya acara ini di dukung oleh adanya etalase (display window) atau ruang peraga khusus. Selian itu, acara ini juga sering disertai dengn pertunjukan film atau atraksi hiburan panggung dengan melibatkan para penari, penyanyi dan artis terkenal, dalam taraf international. Aneka hidangan yang menarik peragaan busana dan berbagai bentuk atraksi lainnya juga sering ditampilkan pada acara seperti itu.

11.Ajang patner khusus (Special Excihibits) yakni pengadaan suatu perlengkapan atau acara tambahan khusus untuk menyemarakkan atau meningkatkan kualitas dan daya tarik lokasi kunjungan. Misalnya: pemasangan karpet merah kehormatan pada gerbang masuk si station kereta apai atau di bandara udara, khusus untuk menyambut dan menyenangkan sekaligus menghormati para pengunjung. (Kusumastuti: 2002:188-189) 
Dalam pameran madrasah variasi di atas dapat digunakan keseluruhannya tinggal yang dipertimbangkan kegiatan itu hanya insidental atau terencana atau terprogram, misalkan satu tahun satu kali, bila hanya sesaat bisa menggunakan variasi pameran kecil ini bisa dilakukan dengan seminggu sekali atau satu bulan sekali berkaitan dengan kegiatan-kegiatan yang akan di capai dalam waktu kurun tertentu. Kalangan tertentu juga bisa menggunakan variasi pameran terbatas ini sangat cocok apabila ada yang melakukan studi banding dari luar. Pameran dagang dalam hal pendidikan dapat dilakukan pada orang-orang penting atau kunci yang mempunyai pengaruh besar terhadap lembaga pendidikan yang bersangkutan dari sudut sosiologis. Selian itu jaga dapat menggunakan pameran jinjing, madrasah melakukan sosialisasi dengan lebih aktif bergerak. Begitu juga pameran keliling yang lebih aktif adalah pihak lembaga. Namun bila melibatkan semua pihak maka bisa menggunakan variasi-variasi yang ada di atas dan hasilnya akan maksimal.

\section{J. Kesimpulan}

Pameran sekolah merupakan wahana informasi atau massage yang disampaikan melalui komunikasi verbal maupun non verbal oleh pihak madrasah kepada masyarakat. Agar hasilnya dapat maksimal perlu adanya perencanaan yang matang dengan melakukan kajian terlebih dahulu mengenai penyelenggaraan waktu, tempat, sarana, humas, biaya, faktor pendukung dan lain sebagainya. Bentuk pameran sangat variatif dan penggunaan bisa jarak pendek (mingguan) maupun jarak jauh (tahunan). Dalam sekolah yang paling bertanggungjawab dalam masalah pameran ini adalah waka humas yang mempunyai posisi sebagai manajer yang memandu semua kegiatan pameran khusunya berkaitan dengan editor jurnal internal, pengatur kunjungan, fotografer, percetakan, dan publikasi dan petugas pers.

Pameran pendidikan merupakan sarana penting untuk mengenalkan institusi lembaga pendidikan terutama madrasah ke semua masyarakat. Dengan pameran pendidikan, masyarakat akan berupaya memilih pendidikan yang terbaik bagi putra-putri mereka. Madrasah merupakan lembaga pendidikan yang bernafaskan agama Islam yang memiliki potensi yang cukup baik dalam mengikuti persaingan di dunia pendidikan. Ikutnya madrasah dalam pameran akan merubah image masyarakat tentang madrasah yang pada awalnya terkesan pendidikan terbelakang menjadi pendidikan yang unggul. Diharapkan dari pameran 
tersebut apa yang menjadi harapan orang tua terhadap pendidikan dalam agama Islam yang berkualitas akan terjawab.

\section{K. Daftar Pustaka}

Anggoro, M. Linggar. 2001. Teori Dan Profesi Kehumasan Serta Aplikasinya Di Indonesia, Bumi Aksara, Jakarta.

Bawani, Imam, 1987. Segi-Segi Pendidikan Islam, Al-Ikhlas, Surabaya.

Djumhur dan Danasaputra, tt. Sejarah Pendidikan Islam, Ilmu, Bandung.

Faisal, Sanapiah. 2003, Format-Format Penelitian Sosial, Raja Grafindo Persada, Jakarta.

Hasan, M. Tolhah. 1993. Muhammadiyah dan NU dalam Reorientasi Pendidikan, LPY, LKPSMU NU, Yogyakarta.

Indrafahrudi, Soekarto. 1994. Bagaimana Mengakrabkan Sekolah dengan Orang Tua Murid dan Masyarakat, IKIP, Malang.

Kusumatuti, Frida. 2002. Dasar-Dasar Humas, Ghalia Indonesia, Jakarta.

Langgulung, Hasan. 1980. Beberapa Pemikiran Tentang Pendidikan Islam, AlMa'arif. Bandung.

Mustofa, Ahmad; Ali, Abdullah. 1997. Sejarah Pendidikan Islam di Indonesia, CV. Pustaka Setia, Bandung.

Media Indonesia Online, 2008; Pameran Pendidikan Luar Negeri Diikuti 14 Negara http://www.mediaindonesia.com, diakses 25 Nopember 2010

Purta, 2008; Adakah Pameran di Purwokerto; http// purworejokita.com diakses 25 Nopember 2010

Ruslan, Rosady. 2002. Manajemen Humas Konsepsi dan Komunikasi Konsepsi dan Aplikasi, Grafindo Persada, Jakarta. 